\title{
A Major Quantitative Trait Locus for Resistance to Potato leafroll virus Is Located in a Resistance Hotspot on Potato Chromosome XI and Is Tightly Linked to $\mathbf{N}$-Gene-Like Markers
}

\author{
Waldemar Marczewski, ${ }^{1}$ Bogdan Flis, ${ }^{1}$ Jerzy Syller, ${ }^{1}$ Ralf Schäfer-Pregl, ${ }^{2}$ and Christiane Gebhardt ${ }^{2}$ \\ ${ }^{1}$ Plant Breeding and Acclimatization Institute, Platanowa 19, PL-05831 Młochów, Poland; ${ }^{2}$ Max-Planck \\ Institut für Züchtungsforschung, Carl von Linne Weg 10, D-50829 Köln, Germany \\ Submitted 6 June 2001; Accepted 5 September 2001.
}

\begin{abstract}
Potato leafroll virus (PLRV) causes one of the most widespread and important virus diseases in potato. Resistance to PLRV is controlled by genetic factors that limit plant infection by viruliferous aphids or virus multiplication and accumulation. Quantitative trait locus (QTL) analysis of resistance to virus accumulation revealed one major and two minor QTL. The major QTL, PLRV.1, mapped to potato chromosome $\mathrm{XI}$ in a resistance hotspot containing several genes for qualitative and quantitative resistance to viruses and other potato pathogens. This QTL explained between 50 and $60 \%$ of the phenotypic variance. The two minor QTL mapped to chromosomes V and VI. Genes with sequence similarity to the tobacco $N$ gene for resistance to Tobacco mosaic virus were tightly linked to $P L R V .1$. The cDNA sequence of an $N$-like gene was used to develop the sequence characterized amplified region (SCAR) marker $\mathrm{Nl27}_{1164}$ that can assist in the selection of potatoes with resistance to PLRV.
\end{abstract}

Potato leafroll virus (PLRV; genus Polerovirus, family Luteoviridae) causes one of the most widespread and important virus diseases in potato (Barker and Waterhouse 1999; Syller 1996). In potato, PLRV infection causes yield reduction ranging from 10 to $95 \%$ (van der Zaag 1987; Watson and Wilson 1956). The distribution of PLRV in infected plants is restricted to the phloem. The virus is persistently transmitted by aphids and is not mechanically transmissible (Casper 1988). Spread of PLRV in the potato crop can be controlled by insecticide application. A more economic and environmentally more acceptable way to control PLRV is the cultivation of potatoes with enhanced resistance (Barker and Waterhause 1999).

There are two main types of resistance to PLRV. One operates against infection by viruliferous aphids and the other one limits virus multiplication and accumulation (Barker and Harrison 1986). The latter type of resistance is of great importance because resistant plants are poor sources of PLRV for the aphid vectors (Barker 1987; Barker and Woodford 1992).

Resistance to PLRV infection has been described as polygenically controlled (Davidson 1973), whereas resistance to

Corresponding author: Christiane Gebhardt;

E-mail: gebhardt@mpiz-koeln.mpg.de
PLRV accumulation seems to be under simple genetic control. Barker and Solomon (1990) and Brown and Thomas (1994) proposed that the second type of resistance is due to a single dominant gene. Later studies supported the hypothesis of two unlinked, dominant complementary genes conferring resistance to PLRV accumulation (Barker et al. 1994). An oligogenic segregation of resistance was also supported by the experiments of Świeżyński and associates (1990). Expression of resistance under major gene control seemed to be modified by other factors (Brown and Thomas 1994). These modifier genes affecting resistance have not been further studied. It is, however, accepted that the presence of a major gene without a suitable genetic background does not sufficiently protect a plant from PLRV (Świeżyński 1993). The description of the inheritance of resistance to PLRV is derived from classical genetic analysis. Map positions of genes for resistance to PLRV and their molecular basis are unknown.

A number of wild and cultivated Solanum species host genes for resistance to PLRV (Barker and Waterhause 1999; Świeżyński 1993). Among others, S. chacoense seems to be the most promising source of resistance for exploitation in potato-breeding programs (Barker and Waterhouse 1999; Brown and Thomas 1994). S. chacoense was part of the pedigree of the diploid interspecific hybrid clone DG83-2025, which carries multiple resistance traits (Zimnoch-Guzowska et al. 2000), including resistance to PLRV accumulation. Thus, the PLRV resistance present in clone DG83-2025 might originate from $S$. chacoense.

In this paper, we report the mapping with DNA markers of resistance to PLRV accumulation in the Erwinia population (Zimnoch-Guzowska et al. 2000), an F1 hybrid family of clone DG83-2025, and the susceptible clone DG81-68. One major and two minor quantitative trait loci (QTL) were identified. The major QTL mapped to potato chromosome XI within a hotspot for resistance to various pathogens and was tightly linked to potato genes with sequence similarity to $N$, a tobacco gene for resistance to Tobacco mosaic virus (TMV) (Whitham et al. 1994).

\section{RESULTS}

PLRV resistance tests.

Parents and 137 F1 plants of the Erwinia population were screened for the relative amount of virus in secondarily in- 
fected plants. When tested by enzyme-linked immunosorbent assay (ELISA) in 1999, PLRV was detected in all tuber progeny plants of the parent DG81-68 and 101 F1 hybrids. For the parent DG83-2025 and the remaining $36 \mathrm{~F} 1$ hybrids, the mean values of two ELISAs did not exceed an $A_{405}$ of 0.2 and were only slightly higher than the values obtained from noninoculated control plants (mean $A_{405}$ values $\leq 0.1$ ). Parent DG83-2025 and the 36 F1 hybrids had been subjected to additional greenhouse inoculation with PLRV by aphids in the previous year. They expressed, therefore, high resistance to PLRV accumulation. The PLRV resistance of these plants was confirmed in the subsequent vegetative generation. The data from two ELISAs were highly correlated $(r=0.91, P<0.001)$. The frequency distribution of mean $A_{405}$ values of 15 plants per genotype for the second ELISA is shown in Figure 1. The distribution exhibited significant positive skewness and negative kurtosis. The number of modes suggests that more than one peak was present (Table 1). The mean $A_{405}$ value of the susceptible parent DG81-68 was close to the population mean.

\section{QTL for PLRV resistance.}

Amplified fragment length polymorphism (AFLP) and restriction fragment length polymorphism (RFLP) markers, in- cluding resistance gene-like (RGL) markers that map to the 12 linkage groups of each parent of the Erwinia population (Zimnoch-Guzowska et al. 2000), were tested for linkage to QTL for PLRV resistance using the $t$ test. Significant $(P<$ 0.01 ) and positive (low $A_{405}$ values) effects were detected in both ELISAs with markers located on linkage groups XI and $\mathrm{V}$ of the PLRV-resistant parent DG83-2025 and on linkage group VI of the susceptible parent DG81-68 (Table 2). Analysis of variance showed that distal markers on the north arm of chromosome XI explained between 48 and $60 \%$ of the phenotypic variance, indicating that a major QTL for PLRV resistance is located in this map region (Table 2, Fig. 2). RFLP marker GP76 identified one of the two smaller effects (Table 2 ) and is located in the distal segment of the south arm of chromosome VI (Gebhardt et al. 1991; Zimnoch-Guzowska et al. 2000). AFLP marker HM4-26 explained between 11 and $16 \%$ of the phenotypic variance and is located on linkage group V of the DG83-2025 parent (data not shown). The AFLP marker allele had a highly distorted segregation ratio (Table 2). The map position of the AFLP locus HM4-26 could not be determined with certainty relative to existing molecular maps of potato chromosome V. No evidence was found for interaction between the three QTL.

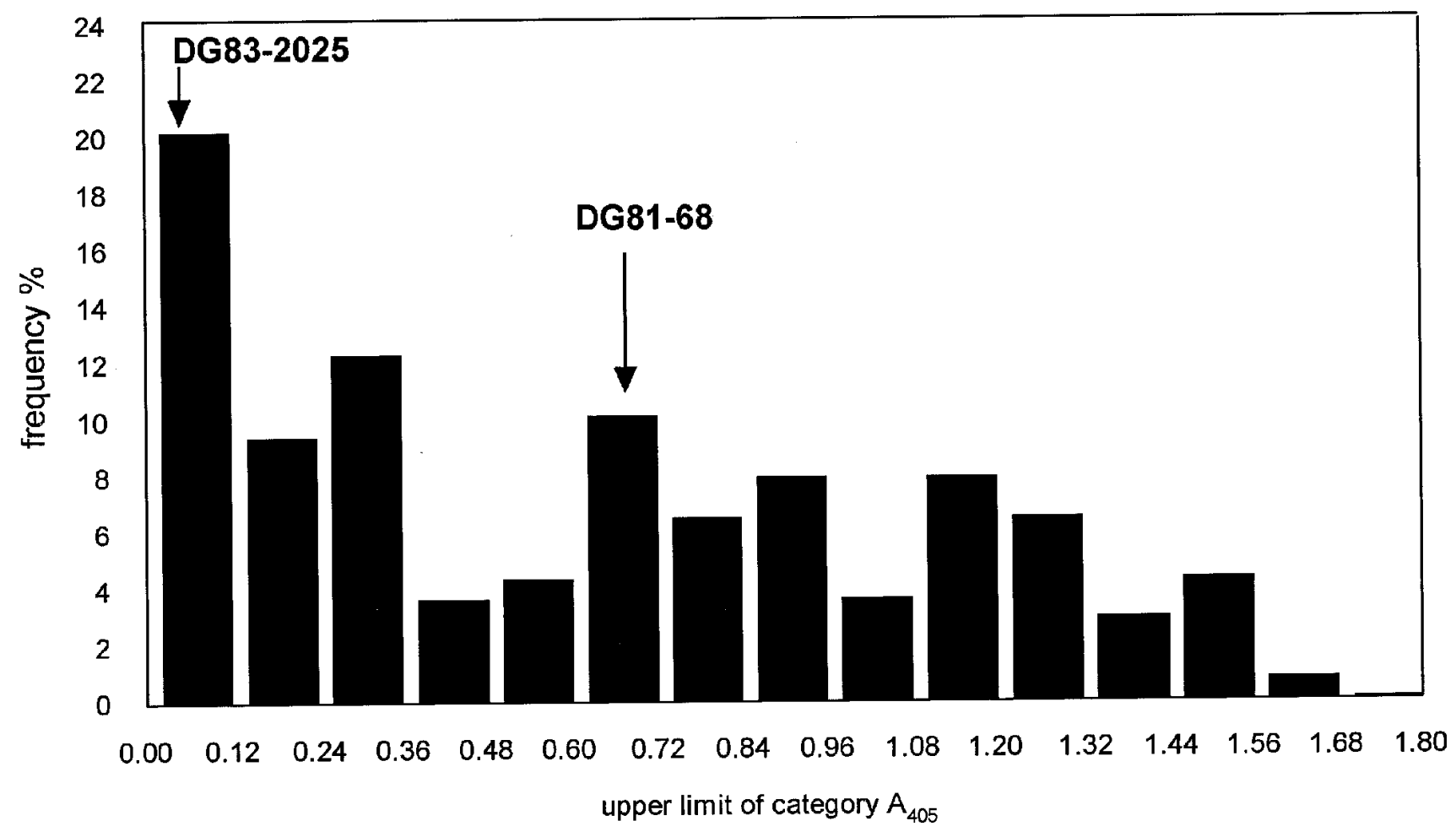

Fig. 1. Frequency distribution of $A_{405}$ values (means of 15 plants per genotype) measured by enzyme-linked immunosorbent assay in $137 \mathrm{~F} 1$ hybrids of the Erwinia population secondarily infected with Potato leafroll virus. The parent values are indicated by arrows. d Kolmogoroff-Smirnoff $=0.1255202$ and $P<0.05$. Chi-square $=24.87698, \mathrm{df}=9$, and $P=0.0031184$.

Table 1. Statistical parameters for the frequency distribution of enzyme-linked immunosorbent assay 2 in the Erwinia population

\begin{tabular}{lccccc}
\hline Plant identification & Mean value of $\boldsymbol{A}_{\mathbf{4 0 5}}$ & Standard deviation & No. of modes & \multicolumn{2}{c}{ Skewness } \\
\hline DG83-2025 & 0.007 & 0.007 & $\ldots{ }^{\text {a }}$ & $\ldots$ & $\ldots$ \\
DG81-68 & 0.680 & 0.228 & $\ldots$ & $\ldots$ & $\ldots$ \\
F1 progeny & 0.617 & 0.468 & 2 & 0.323 & -1.189 \\
\hline
\end{tabular}

a $\ldots=$ Not applicable. 
$N$-like genes linked to PLRV resistance.

The major QTL for PLRV resistance mapped to a position on the potato molecular map, where a cluster of genes with sequence similarity to the tobacco $N$ gene for resistance to

\section{XI}

\section{DG83-2025}

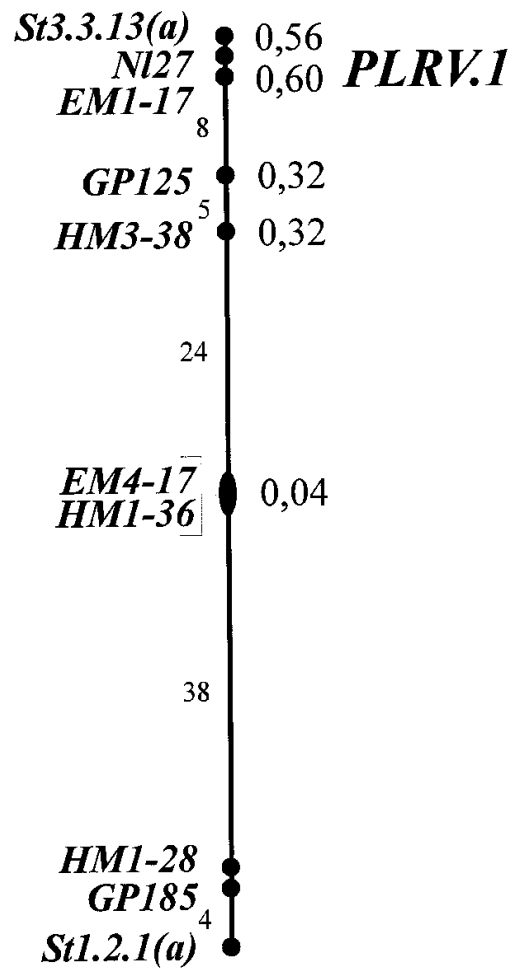

Fig. 2. Position of quantitative trait locus $P L R V .1$ on linkage group XI of the Potato leafroll virus-resistant parent DG83-2025. Restriction fragment length polymorphism (GP125, GP185), amplified fragment length polymorphism $\left(\mathrm{HM}^{*} *_{*}^{*}, \mathrm{EM}^{*} *_{-} * *\right.$; Zimnoch-Guzowska et al. 2000), resistance gene-like marker loci and map distances in cM are shown on the left of the linkage group. The amount of phenotypic variance explained at the marker loci $\left(R^{2}\right)$ in enzyme-linked immunosorbent assay 2 is shown on the right. The sequence characterized amplified region marker $\mathrm{N} 127_{1164}$ explained the largest amount of the phenotypic variance and, therefore, determines the position of PLRV.1.
TMV (Whitham et al. 1994) has been identified (Leister et al. 1996). St3.3.13(a), one of four RFLP loci identified by the $N$ like marker St3.3.13 in the Erwinia population (ZimnochGuzowska et al. 2000) was most closely linked to the QTL PLRV.1 (Table 2, Fig. 2). Full-length cDNA sequences of two members of the St3.3.13 gene family have been described (Hehl et al. 1999). Polymerase chain reaction (PCR) primers were designed for the cDNA Nl-27, resulting in two amplification products of 2 and $1.2 \mathrm{~kb}$ predominantly in the resistant parent DG83-2025. Both PCR fragments segregated in the Erwinia population (Fig. 3). The 2-kb PCR product mapped to linkage group II (data not shown) and the 1.2-kb PCR product mapped to linkage group XI, $1 \mathrm{cM}$ proximal to the $S t 3.3 .13(a)$ locus (Fig. 2). Presence of the 1.2-kb Nl-27 product was linked with increased resistance to PLRV and explained 50 and $60 \%$ of the phenotypic variance in ELISAs 1 and 2, respectively (Table 2). All 36 PLRV resistant F1 plants had the 1.2-kb Nl-27 PCR product.

\section{DISCUSSION}

QTL analysis of resistance to PLRV accumulation identified one major QTL and two additional QTL with smaller effects on three different potato chromosomes. The major QTL PLRV.1 on chromosome XI explained more than $50 \%$ of the phenotypic variance. The presence of one locus with a major effect on resistance explains the bimodal distribution of resistance phenotype. Our findings corroborate the hypothesis, derived from classical inheritance studies, that resistance to PLRV accumulation is controlled largely by a single locus (Barker and Solomon 1990; Brown and Thomas 1994; Flis and Wasilewicz-Flis 1998). Interactions between the major QTL and the secondary effects on chromosomes V and VI were not detected, indicating that these QTL did not interfere with the expression of the major QTL but contributed independently to the overall resistance level. One of the secondary QTL effects at the PLRV.2 locus was inherited from the susceptible parent. This supports earlier observations that the genetic background can influence the observed level of resistance to PLRV due to a major gene (Flis and Wasilewicz-Flis 1998; Świeżyński 1993).

PLRV.1 maps to potato chromosome XI distal to the anchor RFLP marker GP125 and close to the RGL locus St3.3.13(a). This region of the potato genome contains a number of single genes for resistance ( $R$ genes) to various pathogens (Gebhardt and Valkonen 2001). Among those are genes for extreme resistance to Potato virus Y (PVY) (Brigneti et al. 1997;

Table 2. Mapping of quantitative trait locus (QTL) for Potato leafroll virus (PLRV) resistance to potato linkage groups

\begin{tabular}{|c|c|c|c|c|c|c|c|c|c|c|c|c|c|}
\hline \multirow[b]{2}{*}{ QTL } & \multirow[b]{2}{*}{ Marker } & \multirow{2}{*}{$\begin{array}{c}\text { Origin of the } \\
\text { resistance QTL allele }\end{array}$} & \multirow{2}{*}{$\begin{array}{l}\text { Linkage } \\
\text { group }\end{array}$} & \multicolumn{2}{|c|}{$\begin{array}{l}\text { No. of plants per } \\
\text { genotype class }\end{array}$} & \multicolumn{4}{|c|}{$\operatorname{ELISA}^{\mathbf{b}} \mathbf{1}$} & \multicolumn{4}{|c|}{ ELISA 2} \\
\hline & & & & $\mathrm{N}_{1}$ & $\mathbf{N}_{\mathbf{0}}$ & $\mathrm{X}_{1}{ }^{\mathrm{c}}$ & $\mathrm{X}_{0}{ }^{\mathrm{c}}$ & $R^{2 \mathrm{~d}}$ & $P^{\mathrm{e}}$ & $\mathbf{X}_{1}$ & $\mathbf{X}_{0}$ & $R^{2}$ & $P$ \\
\hline PLRV.1 & $N l 27_{1164}$ & DG83-2025 & XI & 60 & 73 & 0.18 & 0.66 & 0.50 & 0.000 & 0.21 & 0.94 & 0.60 & 0.000 \\
\hline PLRV.1 & St3.3.13(a) & DG83-2025 & XI & 40 & 49 & 0.20 & 0.66 & 0.48 & 0.000 & 0.24 & 0.93 & 0.56 & 0.000 \\
\hline PLRV.2 & $G P 76$ & DG81-68 & VI & 30 & 40 & 0.55 & 0.36 & 0.12 & 0.003 & 0.74 & 0.41 & 0.12 & 0.003 \\
\hline PLRV.3 & HM4-26 & DG83-2025 & V & 101 & 32 & 0.39 & 0.65 & 0.11 & 0.000 & 0.51 & 0.94 & 0.16 & 0.000 \\
\hline
\end{tabular}

${ }^{a}$ Two genotype classes are distinguished by presence (1) or absence $(0)$ of a specific allele (polymerase chain reaction, restriction fragment length polymorphism, or amplified fragment length polymorphism) at the specified marker locus.

${ }^{\mathrm{b}}$ ELISA = enzyme-linked immunosorbent assay.

${ }^{c} \mathrm{X}_{1}$ and $\mathrm{X}_{0}$ are the phenotypic means $\left(A_{405}\right)$ of the marker genotype classes.

${ }^{\mathrm{d}} R^{2}$ is the amount of the phenotypic variance explained by the marker.

e $P$ is the probability for the absence of linkage between the QTL and the marker allele. 
Hämäläinen et al. 1997), hypersensitive resistance to Potato virus A (PVA; Hämäläinen et al. 1998, 2000), a gene for resistance to potato wart caused by the fungus Synchytrium endobioticum (Hehl et al. 1999), and a gene for resistance to the root knot nematode Meloidogyne chitwoodi (Brown et al. 1996). Moreover, QTL for resistance to late blight caused by Phytophthora infestans (Leonards-Schippers et al. 1994) and the bacterial pathogen Erwinia carotovora subsp. atroseptica (Zimnoch-Guzowska et al. 2000) have been mapped to the same genome segment. Clustering of genes controlling monogenic and polygenic resistance to pathogens may occur by chance or may be a consequence of reduced recombination fractions in the proximity of the centromere. The resistance gene cluster on chromosome XI has, however, the longest possible distance from the centromere, as it is located at the distal end of the long chromosome arm (Dong et al. 2000). Alternatively, the clustering, particularly of genes for resistance to PVY, PVA, and now PLRV, suggests that some of these genes have a similar molecular basis, either being alleles of a single locus or having evolved from a common ancestor by local gene duplications with subsequent functional diversification. Tightly linked to the resistance gene cluster on the long arm of potato chromosome XI are several genes with sequence similarity to the $N$ gene for resistance to TMV (Hämäläinen et al. 1998; Hehl et al. 1999; Leister et al. 1996; Whitham et al. 1994). Cloned potato genes for resistance to Potato virus $X$ (PVX) (Bendahmane et al. 1999, 2000) and the root cyst nematode Globodera pallida (Van der Vossen et al. 2000) belong to the same superfamily of resistance genes as $N$. The colocalization of $N$-like genes suggests that genes with sequence similarity to known $R$ genes are the molecular basis for some resistance factors in the cluster on chromosome XI, including PLRV.1.

A sequence characterized amplified region (SCAR) marker was developed for PLRV.1 based on the $N$-like cDNA sequence Nl-27 (Hehl et al. 1999). Interestingly, two amplification products were obtained, both present in the PLRV-resis- tant parent, one of which was tightly linked to PLRV.1 on chromosome XI, and the other one mapped to an independent locus on chromosome II. The cDNA Nl-27 is one member of a multigene family. Primers for sequences conserved between different members of the family can detect, therefore, more than one gene. The marker N127 $7_{1164}$ can be used to select for PLRV resistance in offspring of clone DG83-2025. It remains to be tested to what extent this marker is indicative for presence of PLRV resistance in wide germ plasm pools of potato, where resistance to PLRV accumulation can be present separately and in combination with resistance to infection by viruliferous aphids (Dziewońska and Waś 1994; SolomonBlackburn and Barker 1993; Świeżyński et al. 1989). Resistance to infection is controlled by factors of yet unknown map position. The possibility exists that the marker N1-27 $7_{1164}$ is located within or physically very close to the $P L R V .1$ resistance gene. In this case, strong linkage disequilibrium is expected between this marker and presence of the PLRV resistance allele of DG83-2025, even in a wide germ plasm pool. Markers have been found that are diagnostic for the presence of the $R y_{\text {adg }}$ gene for resistance to PVY in a wide potato germ plasm pool (Kasai et al. 2000; Sorri et al. 1999). These markers are based on a different $N$-like sequence that mapped to the same resistance hotspot on potato chromosome XI that includes $R y$ and PLRV.1. PCR markers derived from genes with sequence similarity to $R$ genes are, therefore, highly useful as tools for marker-assisted selection for pathogen resistance.

\section{MATERIALS AND METHODS}

\section{Plant material.}

The population used for mapping PLRV resistance genes was the Erwinia population described by Zimnoch-Guzowska and associates (2000). The parents of the Erwinia population were diploid clones DG83-2025 (seed parent) and DG81-68 (pollen parent). Clone DG83-2025, descending from intercrossing the wild potato species $S$. chacoense and S. yun-

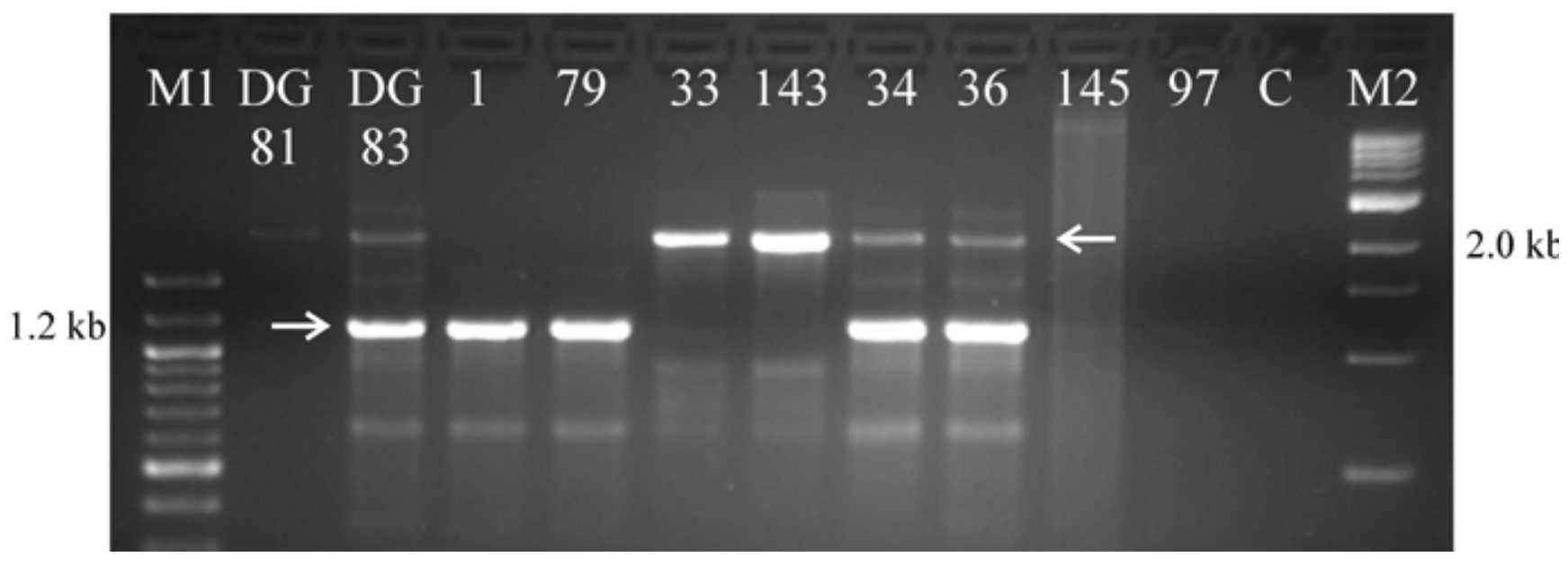

Fig. 3. Electrophoretic patterns of the sequence characterized amplified region marker N127 1164 in the Erwinia population. Lanes are as follows: DG81, the Potato leafroll virus (PLRV)-susceptible parent DG81-68; DG83, the PLRV-resistant parent DG83-2025; 1, 79, 34, and 36, examples for resistant F1 individuals; 33, 143, 145, and 97, examples for susceptible F1 individuals; M1 and M2, molecular-size markers; C, negative control [no template DNA was added to the polymerase chain reaction (PCR)]. Two PCR products of 1.2 and $2 \mathrm{~kb}$ (indicated by the arrows) were obtained in the PLRV-resistant parent DG83-2025, which segregated in the F1 offspring resulting in four different marker phenotypes represented by two plants each: both fragments (lanes 34 and 36), none of the fragments (lanes 145 and 97), either the 1.2-kb fragment (lanes 1 and 79) or the 2-kb fragment (lanes 33 and 143) are present. The 1.2-kb fragment is linked to PLRV.1, whereas the 2-kb fragment is unlinked and maps to linkage group II. 
gasense with S. tuberosum (Zimnoch-Guzowska et al. 2000), was the donor of resistance to PLRV. One hundred thirtyseven F1 individuals of the Erwinia population were available for mapping QTL for PLRV resistance.

\section{Test for resistance to PLRV.}

Since 1995, the Erwinia population (parents and 137 F1 hybrids) were propagated in the field under natural PLRV infection pressure. When tested by quantitative ELISA (Syller 1991) using polyclonal antibodies against PLRV (Goszczyński 1987), the majority of plants of the parent DG81-68 and of 101 F1 hybrids contained high titers of PLRV. Tubers from these infected genotypes were greenhouse propagated in 1997 and 1998. Parent DG83-2025 and 36 F1 hybrids appeared highly resistant to PLRV based on very low virus titers. Plants of these genotypes were inoculated with the virus in 1998. Five single-eye plugs from each genotype were cut and planted in pots under greenhouse conditions in April 1998. The plants were inoculated with PLRV at the initial stage of leaf expansion by using Myzus persicae (Sulzer) aphids that had been kept for at least 1 week on the PLRV-infected cultivar Osa. The aphids were transferred onto test plants with pieces of infected source leaves. In addition, shaking PLRV-infected shoots that were colonized by aphids over the test plants ensured strong infection pressure (Syller 1991). Transmission of PLRV to Physalis floridana Rydb. plants was used as a positive control of the aphid inoculation procedure. The aphids were allowed to acquire and inoculate PLRV in feedings over a period of 3 days. After inoculation, plants were grown in a greenhouse under 12-h light conditions at 19 to $25^{\circ} \mathrm{C}$ and tubers were harvested. In spring 1999, tuber progeny plants of parents and all 137 hybrid clones (15 plants per genotype) were planted in the greenhouse and tested twice by ELISA (between 4 and 6 weeks after planting), as described by Syller (1991). Both ELISAs were done for all plants on the same date. ELISA readings were taken after $1 \mathrm{~h}$ of incubation with substrate at room temperature and averaged over 15 plants of each genotype. Tubers of the most resistant clones were again examined by ELISA in the 2000 season.

\section{DNA marker analysis.}

Genotyping with AFLP (Vos et al. 1995), RFLP and RGL markers, and linkage map construction were described earlier (Zimnoch-Guzowska et al. 2000). The SCAR marker N127 1164 was amplified using approximately $50 \mathrm{ng}$ of template DNA in $50 \mu \mathrm{l}$ of $20 \mathrm{mM}$ Tris- $\mathrm{HCl}, \mathrm{pH} 8.4 ; 50 \mathrm{mM} \mathrm{KCl} ; 0.1 \mathrm{mM}$ of each dNTP; $1.5 \mathrm{mM} \mathrm{MgCl} ; 0.23 \mu \mathrm{M}$ each of the primers N127-f (5'-TAGAGAGCATTAAGAAGCTGC-3') and N127-r (5'-TTTTGCCTACTCCCGGCATG-3'); and $1 \mathrm{U}$ of Taq DNA polymerase (Gibco BRL, Karlsruhe, Germany). The primers were complementary to positions 57 to 77 and 853 to 872 , respectively, of the cDNA sequence N1-27 (EMBL accession no. AJ009720) described by Hehl and associates (1999). PCR conditions were 1 cycle of $93^{\circ} \mathrm{C}$ for $60 \mathrm{~s}$, followed by 35 cycles of $93^{\circ} \mathrm{C}$ for $30 \mathrm{~s}, 62^{\circ} \mathrm{C}$ for $30 \mathrm{~s}, 72^{\circ} \mathrm{C}$ for $90 \mathrm{~s}$, and a final extension time of $10 \mathrm{~min}$ at $72^{\circ} \mathrm{C}$. PCR products were size-separated by electrophoresis in $1.5 \%$ agarose and visualized by ethidium bromide staining under standard conditions (Sambrook et al. 1989).

\section{QTL analysis and statistics.}

All marker fragments scored in the Erwinia population were tested for effect on PLRV resistance using the $t$ test, as described by Zimnoch-Guzowska and associates (2000). Analysis of variance for single markers and testing for interaction between markers was done using SPSS software (SPSS Base 10.0; SPSS GmbH Software, München, Germany). The distribution of the phenotypic data was tested for normality based on a goodness of fit $\left(\chi^{2}\right)$ test.

\section{ACKNOWLEDGMENTS}

The authors thank E. Zimnoch-Guzowska and F. Salamini for critically reading of the manuscript. Part of this work was carried out in the department of F. Salamini at the MPI für Züchtungsforschung, Köln, Germany. Excellent technical assistance was provided by H. Henselewski.

\section{LITERATURE CITED}

Barker, H. 1987. Multiple components of the resistance of potatoes to potato leaf roll virus. Ann. Appl. Biol. 111:641-648.

Barker, H., and Harrison, B. D. 1986. Restricted distribution of potato leafroll virus antigen in resistant potato genotypes and its effect on transmission of the virus by aphids. Ann. Appl. Biol. 109:595-604.

Barker, H., and Solomon, R. M. 1990. Evidence of simple genetic control in potato of ability to restrict potato leafroll virus concentration in leaves. Theor. Appl. Genet. 80:188-192.

Barker, H., and Waterhouse, P. M. 1999. The development of resistance to luteoviruses mediated by host genes and pathogen-derived transgenes. Pages 169-210 in: The Luteoviridae. H. G. Smith and H. Barker, eds. CAB Int., Wallingford, UK

Barker, H., and Woodford, J. A. T. 1992. Spread of potato leafroll virus is decreased from plants of potato clones in which virus accumulation is restricted. Ann. Appl. Biol. 121:345-354.

Barker, H., Solomon-Blackburn, R. M., McNicol, J. W., and Bradshaw, J. E. 1994. Resistance to potato leaf roll virus multiplication is under major gene control. Theor. Appl. Genet. 88:754-758.

Bendahmane, A., Kanyuka, K., and Baulcombe, D. C. 1999. The $R x$ gene from potato controls separate virus resistance and cell death responses. Plant Cell 11:781-791.

Bendahmane, A., Querci, M., Kanyuka, K., and Baulcombe, D. C. 2000. Agrobacterium transient expression system as a tool for the isolation of disease resistance genes: Application to the $R \times 2$ locus in potato. Plant J. 21:73-81

Brigneti, G., Garcia-Mas, J., and Baulcombe, D. C. 1997. Molecular mapping of the potato virus $\mathrm{Y}$ resistance gene $R y_{\text {sto }}$ in potato. Theor. Appl. Genet. 94:198-203.

Brown, C. R., and Thomas, P. E. 1994. Resistance to potato leafroll virus derived from Solanum chacoense: Characterization and inheritance. Euphytica 74:51-57.

Brown, C. R., Yang, C-P., Mojtahedi, H., and Santo, G. S. 1996. RFLP analysis of resistance to Columbia root-knot nematode derived from Solanum bulbocastanum in a $\mathrm{BC}_{2}$ population. Theor. Appl. Genet. 92: 572-576.

Casper, R. 1988. The plant viruses, polyhedral virions with monopartite RNA genomes. Pages 235-258 in: Luteoviruses. R. Koenig, ed. Plenum Press, New York.

Davidson, T. M. W. 1973. Assessing resistance to leafroll in potato seedlings. Potato Res. 16:99-108.

Dong, F., Song, J., Naess, S. K., Helgeson, J. P., Gebhardt, C., and Jiang, J. 2000. Development and applications of a set of chromosome-specific cytogenetic DNA markers in potato. Theor. Appl. Genet. 101: 1001-1007.

Dziewońska, M. A. and Waś, M. 1994. Diploid genotype DW84-1457, highly resistant to potato leafroll virus (PLRV). Potato Res. 37:217-224.

Flis, B., and Wasilewicz-Flis, I. 1998. Progeny tests to identify diploid potato clones homozygous at loci controlling resistance to PLRV. Potato Res. 41:219-228.

Gebhardt, C., Ritter, E., Barone, A., Debener, T., Walkemeier, B., Schachtschabel, U., Kaufmann, H., Thompson, R. D., Bonierbale, M. W., Ganal, M. W., Tanksley, S. D., and Salamini, F. 1991. RFLP maps 
of potato and their alignment with the homeologous tomato genome. Theor. Appl. Genet. 83:49-57.

Gebhardt, C., and Valkonen, J. P. T. 2001. Organization of genes controlling disease resistance in the potato genome. Annu. Rev. Phytopathol. 39:79-102.

Goszczyński, D. 1987. Potato leafroll virus (PLRV)-purification, obtaining of specific serum. Biul. Inst. Ziemniaka 36:37-41.

Hämäläinen, J. H., Watanabe, K. N., Valkonen, J. P. T., Arihara, A., Plaisted, R. L., Pehu, E., Miller, L., and Slack, S. A. 1997. Mapping and marker-assisted selection for a gene for extreme resistance to potato virus. Y. Theor. Appl. Genet. 94:192-197.

Hämäläinen, J. H., Sorri, V. A., Watanabe, K. N., Gebhardt, C., and Valkonen, J. P. T. 1998. Molecular examination of a chromosome region that controls resistance to potato $\mathrm{Y}$ and A potyviruses in potato. Theor. Appl. Genet. 96:1036-1043.

Hämäläinen, J. H., Kekarainen, T., Gebhardt, C., Watanabe, K. N., and Valkonen, J. P. T. 2000. Recessive and dominant genes interfere with the vascular transport of Potato virus A in diploid potatoes. Mol. Plant-Microbe Interact. 13:402-412.

Hehl, R., Faurie, E., Hesselbach, J., Salamini, F., Whitham, S., Baker, B., and Gebhardt, C. 1999. TMV resistance gene $N$ homologues are linked to Synchytrium endobioticum resistance in potato. Theor. Appl. Genet. 98:379-386.

Kasai, K., Morikawa, Y., Sorri, V. A., Valkonen, J. P. T., Gebhardt, C., and Watanabe, K. N. 2000. Development of SCAR markers to the PVY resistance gene $R y_{\text {adg }}$ based on a common feature of plant disease resistance genes. Genome 43:1-8.

Leister, D., Ballvora, A., Salamini, F., and Gebhardt, C. 1996. A PCR based approach for isolating pathogen resistance genes from potato with potential for wide application in plants. Nature Genet. 14:421429.

Leonards-Schippers, C., Gieffers, W., Schäfer-Pregl, R., Ritter, E., Knapp, S. J., Salamini, F., and Gebhardt, C. 1994. Quantitative resistance to Phytophthora infestans in potato: a case study for QTL mapping in an allogamous plant species. Genetics 137:67-77.

Sambrook, J., Fritsch, E. F., and Maniatis, T. 1989. Molecular Cloning: A Laboratory Manual. 2nd ed. Cold Spring Harbor Laboratory Press, Cold Spring Harbor, NY, U.S.A.

Solomon-Blackburn, R. M., and Barker, H. 1993. Resistance to potato leafroll luteovirus can be greatly improved by combining two independent types of heritable resistance. Ann. Appl. Biol. 122:329-336.

Sorri, V. A., Watanabe, K. N., and Valkonen, J. P. T. 1999. Predicted kinase 3a motif of a resistance gene-like fragment as a unique marker for PVY resistance. Theor. Appl. Genet. 99:164-170.

Syller, J. 1991. The effects of temperature on the susceptibility of potato plants to infection and accumulation of potato leafroll virus. J. Phytopathol. 133:216-224.

Syller, J. 1996. Potato leafroll virus (PLRV): Its transmission and control. Integr. Pest Manage. Rev. 1:217-227.

Świeżyński, K. M. 1993. Inheritance of resistance to viruses. Pages 339363 in: Potato Genetics. J. E. Bradshaw, and G. R. Mackay, eds. CAB Int., Wallingford, U.K.

Świeżyński, K. M., Dziewońska, M. A., and Ostrowska, K. 1989. Resistance to the potato leafroll virus (PLRV) in diploid potatoes. Plant Breed 103:221-227.

Świeżyński, K. M., Dziewońska, M. A., and Ostrowska, K. 1990. Inheritance of the potato leafroll virus (PLRV) in the potato. Pages 538-539 in: Abstr. 11th Triennial Conf. of the Eur. Assoc. for Potato Research (EAPR), D. K. L. MacKerron, H. D. Edmond, D. Hall, M. A. Kirkman, R. W. Lang, G. R. Mackay, D. C. McRae, and J. P. Oxley, eds.

Van der Zaag, D. E. 1987. Yield reduction in relation to virus infection. Pages 146-150 in: Virus of Potatoes and Seed-Potato Production. J. A. de Box, and J. P. H. van der Want, eds. Pudoc, Wageningen, The Netherlands.

Van der Vossen, E. A. G., Rouppe van der Voort, J. N. A. M., Kanyuka, K., Bendahmane, A., Sandbrink, H., Balcombe, D. C., Bakker, J., Stiekema, W. J., and Klein-Lankhorst, R. M. 2000. Homologues of a single resistance-gene cluster in potato confer resistance to distinct pathogens: A virus and a nematode. Plant J. 23:567-576.

Vos, P. R., Hogers, M., Bleeker, M., Reijans, T., van de Lee, M., Hornes, A., Frijters, J., Pot, J., Peleman, M., Kuiper, M., and Zabeau, M. 1995. AFLP: A new technique for DNA fingerprinting. Nucleic Acids Res. 23:4407-4414.

Watson, D. J., and Wilson, J. H. 1956. An analysis of the effects of infection with leaf-roll virus on the growth and yield of potato plants, and of its interactions with nutrient supply and shading. Ann. Appl. Biol. 44:390-409.

Whitham, S., Dinesh-Kumar, S. P., Choi, D., Hehl, R., Corr, C., and Baker, B. 1994. The product of the tobacco mosaic virus resistance gene $N$ : Similarity to Toll and the Interleukin-1 receptor. Cell 78: 1101-1115.

Zimnoch-Guzowska, E., Marczewski, W., Lebecka, R., Flis, B., SchäferPregl, R., Salamini, F., and Gebhardt, C. 2000. QTL analysis of new sources of resistance to Erwinia carotovora subsp. atroseptica in potato done by AFLP, RFLP and resistance-gene-like markers. Crop Sci. 40:1156-1167. 